BOŻENA ZBOINA, BARBARA KAŁDON

HALINA KRÓL

BARBARA BAKALARZ-KOWALSKA

Wyższa Szkoła Biznesu i Przedsiębiorczości w Ostrowcu Św.

Uniwersytet Jana Kochanowskiego w Kielcach

\title{
KRYZYSY W STAROŚCI W UJĘCIU PEDAGOGICZNYM
}

\section{CRISES IN OLD AGE - TEACHING APPROACH}

\section{Streszczenie}

Artykuł dotyczy sytuacji trudnych (kryzysów), które występują wśród ludzi starszych. Zależą one od warunków wewnętrznych, osobowościowych, indywidualnych dla każdego człowieka oraz zewnętrznych, związanych ze stylem życia, oddziaływań społecznych. Jako sytuacje trudne przedstawiono stan samotności i osamotnienia, lęk przed śmiercia, okres przejścia na emeryturę i wiążącą się z tym utratę dotychczasowej roli społecznej, przymusową bezczynność, utratę kondycji fizycznej, chorobę, socjoekonomiczne warunki życia.

Slowa kluczowe: starość, kryzysy w starości, sytuacje trudne.

\section{Summary}

The article is regarding difficult situations (of crises) which are appearing among the elderly. They depend on internal, personality, individual conditions for every man and outside, associated with a lifestyle, of social influences. As difficult situations a condition of the solitude and lonelinesses, a fear of death, a period of the retirement and loss being connected with it were presented for current social role, compulsory 
inactivity, loss of the physical fitness, illness, socjoekonomiczne living conditions.

Key words: senility, crises in old age, difficult situations

\section{WPROWADZENIE}

Obecne i nadchodzące prognozy demograficzne nie dają możliwości osiagnięcia tak ważnego celu, jakim jest zapewnienie ludziom spokojnej, twórczej i szczęśliwej starości. Jednak, pomimo trudności, w dobrze rozumianym interesie społeczeństwa jest pojęcie wspólnych projektów i działań, gwarantujących ludziom dobrą starość.

Najważniejszą rolę w kształtowaniu zadań polityki społecznej wobec ludzi starszych. stanowią przesłanki zakwalifikowane do grupy ekonomicznej, zdrowotnej i socjalnej, odnoszące się bardziej do tych aspektów sytuacji społecznej ludzi starszych, które eksponują ich słabszą pozycję w stosunku do reszty społeczeństwa. Pomija się tutaj niejako grupę przesłanek kulturowych, w tym $\mathrm{m}$. in. przestrzeganie norm społecznych dotyczących pozycji i stosunku do ludzi starszych, borykających się z różnego typu trudnymi sytuacjami. Poznanie ich być może przyczyni się do zmiany polityki społecznej, która powinna być wielokierunkowa, realizowana we wszystkich aspektach życia społecznego, co jest ważne ze względu na możliwości udzielania i uzyskiwania pomocy.

\section{SYTUACJE KRYZYSOWE W ŻYCIU CZŁOWIEKA}

W życiu każdego człowieka, także ludzi starszych, występują trudne sytuacje. Mówimy wówczas o kryzysie. Za synonimy tego pojęcia uważa się słowa: niż, impas, wyłom, przesilenie, zmiana. Według Wielkiej Encyklopedii PWN, kryzys to: „okres załamania, przesilenia i potencjalnego przełomu w funkcjonowaniu"1. W psychologii pojęcie kryzysu używa-

${ }^{1}$ Wielka Encyklopedia PWN. T. 15, red. nacz. J. Wojnowski, Warszawa 2003, s. 91. 
ne jest często zamiennie z takimi pojęciami jak: stres, konflikt, sytuacja krytyczna, sytuacja trudna, frustracja. Kryzys jest stanem dezorganizacji, w którym człowiek staje w obliczu zniweczenia ważnych celów życiowych lub głębokiego zaburzenia swego cyklu życiowego i metod radzenia sobie z czynnikami stresującymi ${ }^{2}$. W. Badura-Madej definiuje kryzys jako „przejściowy stan nierównowagi wewnętrznej, wywołany przez krytyczne wydarzenie bądź wydarzenie życiowe, wymagający istotnych zmian i rozstrzygnięć" ${ }^{3}$. Kryzys pojmujemy jako zakłócenie w normalnym funkcjonowaniu, to odczuwanie lub doświadczanie wydarzenia bądź sytuacji jako trudności nie do zniesienia, wyczerpującej zasoby wytrzymałości i naruszającej mechanizmy radzenia sobie z trudnościami. Towarzyszą mu zawsze przemiany wewnętrzne, a także konieczność uczenia się nowych zachowań. Osoby dotknięte kryzysem mogą radzić sobie z sytuacją kryzysowa, która jest dla nich okazją zarówno do rozwoju osobowości, jak i znalezienia sensu własnego istnienia. $\mathrm{W}$ takiej sytuacji, zdarzenie kryzysowe staje się okazją do nabycia nowych umiejętności ${ }^{4}$ lub poddania się już na samym początku kryzysu, wykazując niezdolność do normalnego życia, o ile nie pojawi się pomoc z zewnątrz ${ }^{5}$.

Starość jest właśnie takim okresem, którego nie da się uniknąć i który napawa człowieka lękiem i obawą. Przez wiele osób w różnym wieku postrzegana jest jako cykl życia mało atrakcyjny i niegodny pożądania, któremu towarzyszą kryzysy, wobec których często jest się bezradnym i narażonym na wiele strat. W podeszłym wieku wiele problemów ludzie odczuwają intensywniej, mimo że w latach wcześniejszych one też istniały, ale były przez ludzi niezauważane. S. Steuden podzieliła te trudności na kilka grup związanych z:

- sytuacją finansowa, lokomocja, codziennymi obowiązkami domowymi,

- nabyciem nowych umiejętności niezbędnych przy obsłudze urządzeń technicznych (telefon komórkowy, internet),

2 R. K.James, B. E. Gilliland, Strategie Interwencji Kryzysowej, PARPA, Warszawa 2006.

3 cyt. za: B. Szatur- Jaworska, P. Błędowski, M. Dzięgielewska, Podstawy gerontologii spolecznej, Warszawa 2006, s. 65.

4 B. Pilecka, Kryzys psychologiczny, Kraków 2004.

5 R. K.James, B. E. Gilliland, Strategie Interwencji, op. cit. 
- zmianami w relacjach z rodziną i najbliższym otoczeniem (brak zrozumienia),

- zmianą miejsca zamieszkania związaną z sytuacją finansową bądź zdrowotna,

- negatywnym bilansem własnego życia, negatywna samoocena, brakiem akceptacji,

- negatywnych zdarzeniami życiowymi (śmierć bliskiej osoby, pogorszenie stanu zdrowia) . $^{6}$

Inni autorzy opisujsujący sytuacje trudne, występujące w realnym życiu jednostki uważają że mogą one przyjmować dwojaką postać: trudności w rozwiązywaniu zadań życiowych i trudności wynikających z przeciwności losu.

- W przypadku trudności w rozwiązywaniu zadań życiowo ważnych, człowiek za pomocą dotychczasowych mechanizmów zachowania nie jest $\mathrm{w}$ stanie poradzić sobie z problemami, co prowadzi do zaburzenia równowagi psychicznej i wymaga wypracowania nowych sposobów radzenia sobie w nowej sytuacji.

- Trudności mające charakter przeciwności losu, np. choroba, nieszczęśliwy wypadek, a nie związane bezpośrednio z realizacją życiowych dążeń dotyczą kryzysów losowych, które zaskakują człowieka tak, że nie wie on, jak postępować. Nie potrafi poradzić sobie z trudnościami, które wymagają zmiany zachowania, a nawet zmiany struktury wewnętrznej. Czasem może także dojść do podważenia dotychczasowej wartości i sensu życia. Człowiek stara się znaleźć wyjście z sytuacji, poszukuje różnych dróg, ale niekiedy okazuje się bezradny lub brak mu sił na zmianę zachowania. Te kryzysy mogą być niebezpieczne, gdyż skłaniają do nieprawidłowych rozwiązań, mogą też powodować działania, służące obniżeniu przykrych doznań i doświadczeń w poszukiwaniu ukojenia w alkoholu, lekach (uspokajających, nasennych) lub wręcz w autoagresji czy myślach samobójczych ${ }^{7}$.

\footnotetext{
6 S. Steuden, Psychologia starzenia się i starości, Warszawa 2011, s. 25.

7 B. Szatur-Jaworska, P. Błędowski, M. Dzięgielewska, Podstawy..., s. 69-72.
} 
Zatem funkcjonowanie ludzi w starszym wieku zależne jest od wielu zazębiających się uwarunkowań wewnętrznych, które leżą poza zasięgiem wpływów współczesnego człowieka, oraz zewnętrznych, czyli losu, stylu życia, a także oddziaływań społecznych zależnych od ludzi. Ten, kto jest w sytuacji kryzysowej, potrzebuje zrozumienia, cierpliwego wysłuchania i empatii drugiego człowieka. W trakcie przeżywania kryzysu człowiek przekonuje się, jak bliska i pomocna może być druga osoba. Okazywana w kontaktach niechęć ludziom starszym, powoduje ograniczenie aktywności, a w konsekwencji alienację tych osób ze społeczeństwa, co przyspiesza proces starzenia się.

Wśród sytuacji trudnych typowych dla okresu starzenia wyróżnia się między innymi: stan samotności i osamotnienia, lęku, przejście na emeryturę, żałobę, zmianę miejsca zamieszkania, warunki socjoekonomiczne.

Stan samotności i osamotnienia często wynika z niezaspokojenia potrzeb, takich jak:

- bezpieczeństwo (w starszym wieku nasilają się niepokoje i poczucie zagrożenia) $)^{8}$,

- przynależność (drastyczny spadek kontaktów w porównaniu z okresem zatrudnienia, problemem staje się osamotnienie) $)^{9}$,

- uzależnienie (poszukiwanie opieki i postrzeganie jej jako obowiązku otoczenia wobec starego człowieka) ${ }^{10}$.

\section{SAMOTNOŚĆ I OSAMOTNIENIE}

Pojęcia osamotnienia i samotności są niejednoznaczne, funkcjonuje wiele ich definicji przypisujących tym zjawiskom różne cechy. Jednym z głównych społecznych źródeł samotności jako sytuacji, stanu oraz sposobu przeżywania jest zbieżność między wymaganiami stawianymi nam przez role społeczne, a naszymi sądami o samym sobie.

${ }^{8}$ B. Zboina, Jakość życia osób starszych, Ostrowiec Św. 2008, s. 66.

9 Tamże.

10 B. Synak, Teoretyczne i pojęciowe problemy złożoności w starszym wieku, [w:] J. Staręga-Piasek, B. Synak (red.), Społeczne aspekty starzenia się i starości, Warszawa1990, s. 88-108. 
Samotność określa więc zawsze sytuację społeczną osoby i może być rozpatrywana jako:

- stan subiektywnego odczucia, niezależnego od liczby kontaktów społecznych, którego natężenie zależy od oczekiwań, jakie się ma w stosunku do innych, a które może być wynikiem monotonii i nudy ${ }^{11}$,

- stan najgłębszej refleksji nad sensem własnego życia i świata ${ }^{12}$,

- odczuwana bezradność wobec wrogiego świata, przed którym nie można się obronić ${ }^{13}$,

- samotność obiektywna i subiektywna, która jest zarówno formalna postacią sytuacji życiowej (samotne mieszkanie), jak i formą psychicznej i społecznej egzystencji (jako spostrzegany deficyt pozytywnych uczuć ze strony innych osób, szczególnie darzonych uczuciami) ${ }^{14}$.

Kiedyś ludzie samotni żyli na pustkowiu, daleko od siedlisk ludzkich, zwano ich pustelnikami. Obecnie najwięcej osób samotnych spotyka się w wielkich aglomeracjach miejskich i wśród nich jest duży odsetek ludzi starych. Ich dramat rozgrywa się w czterech ścianach, a izolacja często wynika z choroby, opuszczenia, niepełnosprawności ${ }^{15}$.

Wiele znaczeń posiada również pojęcie osamotnienia, o którym decydować mogą pewne stałe i zmienne czynniki podmiotowe (zdrowie, energia życiowa, płeć, samoocena) i sytuacyjne (czas, pieniądze, status i wsparcie społeczne). Bardzo istotną rolę odgrywa indywidualna percepcja well-being (zadowolenie $\mathrm{z}$ życia). Takie podejście prezentuje wielu autorów (A. R. Campbell, N. D. Glenn, M. Andrews, C. N. Weaver i S. B. Withey), utożsamiając je z życiem poza zespołem lu-

\footnotetext{
${ }^{11}$ M. Susułowska, Niektóre aspekty pracy zawodowej ludzi w starszym wieku, [w:] Encyklopedia seniora, Warszawa 1986, s. 79.

12 I. Pufal-Struzik, Poczucie osamotnienia i lęku u ludzi starszych, [w:] A. Jopkiewicz, E. Trafiałek (red.), Trzeci wiek bez starości, Kielce 2000, s. 87.

13 T. Sosnowski, K. Wrzesiński, Polska adaptacja Inwentarza STAI do badania stanu i cech leku, „Przegląd Psychologiczny” nr 2, s. 393-413.

14 K. Łukaszewski, Szanse rozwoju osobowości, Warszawa 1974.

15 J. Rembowski, Psychologiczne problemy starzenia się człowieka, Warszawa-Poznań 2000, s. 45 i nast.
} 
dzi, poza ich sprawami oraz poza środowiskiem ${ }^{16}$. Większość autorów wskazuje na różnice między samotnością a osamotnieniem, najczęściej ujmując samotność jako stan obiektywny - fizyczny, oznaczający brak kontaktów z rodziną i innymi osobami. Osamotnienie zaś rozumie jako subiektywny stan psychiczny jednostki, związany z poczuciem utraty istotnej osoby lub wartości ${ }^{17}$. Interpretując poczucie osamotnienia $\mathrm{w}$ starszym wieku, B. M. Puchalska akcentuje to, że łączy się ono nie tylko z rzeczywistą izolacją i brakiem zainteresowania ze strony dzieci, ale także z wyobrażeniami co do intensywności spotkań rodzinnych i towarzyskich, nudą i nieumiejętnością wypełnienia czasu oraz wzmożoną potrzebą uznania i sprawowania nad kimś kontroli ${ }^{18}$.

Czynnikiem, który może potęgować przykrą reakcję na odczuwaną samotność jest lęk, wobec którego człowiek czuje się bezradny. Lęk zaliczany jest do grupy reakcji emocjonalnych, wyzwalanych przez bodźce z zewnątrz bądź z wnętrza organizmu, nad którymi człowiek czasami nie potrafi zapanować, traktowany jako reakcja czy stan emocjonalny albo jako predyspozycja czy też gotowość do takiego reagowania ${ }^{19}$. W pierwszym przypadku, gdy lęk jest stanem, ma on charakter złożonej reakcji emocjonalnej, na którą składają się subiektywne poczucie napięcia i zagrożenia. Natomiast lęk jako cecha jest bardziej trwałą dyspozycją do reagowania i spostrzegania różnych sytuacji jako zagrażających, np. własnej starości i związanych z nią chorób czy zmianą miejsca zamieszkania ${ }^{20}$.

Wielu ludzi odczuwa większy lub mniejszy strach przed zbliżająca się śmiercią, chociaż wachlarz uczuć, które wiążą się z tym zjawiskiem,

16 A. R. Campbell, P. Converse, W. Rodgers, The quality of life. Perceptions, evaluation and satisfaction, Sage, New York 1976; N. D. Glenn, C. N. Weaver, Educating effects on psychological well-being, Public Opinion Quarterly, 1981, nr 45, s. 22-39; F. M. Andrews, S. B. Withey, Social indicators of well-being. Plenum, New York 1976.

17 P. Czekanowski, Pojęcia i wskaźniki dydaktyczne osamotnienia osób w starszym wieku, [w:] J. Staręga-Piasek, B. Synak (red.), Spoleczne aspekty..., s. 66.

18 B. M. Puchalska, Lęki i niepokoje ludzi starszych, [w:] Encyklopedia seniora, Warszawa 1986, s. 64-65.

19 T. Sosnowski, K. Wrzesiński, Polska adaptacja..., s. 398-413.

20 I. Pufal-Struzik, Poczucie osamotnienia i lęku..., s. 88- 89. 
jest bardzo szeroki. Emocje mogą lokować się od akceptacji i oczekiwania poprzez ignorowanie, aż do silnych stanów lękowych i agresji ${ }^{21}$. Lęk przed śmiercią składa się z kilku etapów: żalu przed opuszczeniem tego świata; przeświadczenia, że nie ma innego życia po śmierci, a tylko nicość; obawy czekającej kary za grzechy, obawy przed samym umieraniem i związanym $\mathrm{z}$ tym cierpieniem $\mathrm{z}$ utratą godności. Istnieją trzy postawy wobec śmierci wśród ludzi starszych:

- pozytywna: jako obietnica nowego, lepszego życia,

- obronna: nie mam powodu myśleć o śmierci, czuję się dobrze,

- lękowa: to koniec wszystkiego 22 .

Według skali oceny przystosowania społecznego badającego poziom stresu związanego z określonymi wydarzeniami życiowymi, śmierć współmałżonka ma najwyższą wartość 100 punktów ${ }^{23}$. Wdowieństwo jest okresem głębokiego smutku i bólu. Okres żałoby jest bardzo ciężki dla osoby starszej i bardzo często nie znajduje ona żadnej pomocy w tym stanie.

Innym wydarzeniem mającym 45 punktów wg wyżej wymienionej skali, na które występuje reakcja lękowa, istotnie rzutując na życie starzejącego się człowieka, jest zakończenie pracy zawodowej. Przejście na emeryturę jest postrzegane jako drastyczne wtargnięcie w życie jednostki. Sytuacja taka powoduje u ludzi poczucie utraty bezpieczeństwa, strach przed przyszłością, na której przebieg w ich mniemaniu nie mają wpływu. Czują się zawiedzeni i okradani z własnej przeszłości ${ }^{24}$. Praca bowiem była często jedynym sposobem realizacji własnych umiejętności, budowania autorytetu i społecznego prestiżu. Praca stanowi podstawową domenę działalności dorosłego człowieka, kształtuje sposób spędzania czasu, ma zasadniczy wpływ na poczucie zadowolenia z życia ${ }^{25}$. Praca, będąca źró-

21 Z. Pietrasiński, Rozwój człowieka dorosłego, Warszawa 1990, s. 110-117.

22 B. Szatur-Jaworska, P. Błędowski, M. Dzięgielewska, Podstawy..., s. 76.

23 A. Birch, T. Malim, Psychologia rozwoju w zarysie. Od niemowlęctwa do dorostości, Warszawa 2001, s. 143-144.

24 O. Czerniewska, Wymiar czasu a przė̇ywanie starości, „Ethos” 1999, nr 47, s. 83.

${ }^{25}$ M. Susułowska, Niektóre aspekty pracy zawodowej ludzi..., s. 118. 
dłem utrzymania, a także realnym wkładem jednostki w dorobek kraju, ma zatem dla większości ludzi ogromne znaczenie. Przekroczenie granicy wieku emerytalnego i wyłączenie z pracy zawodowej, które często traktowane jest jako umowny początek starości, stanowi moment graniczny i nie pozostaje bez wpływu na osobowość jednost$\mathrm{ki}^{26}$. Okres ten przez gerontologów określany jest mianem „szoku emerytalnego" 27 lub ,gilotyny emerytalnej" 28 .

Nowość i ogrom zmian, jakie fakt przejścia na emeryturę wnosi ze sobą w życie człowieka, staje się momentem przełomowym, stanowiącym podstawę dalszego funkcjonowania. Zmusza niejako do reorganizacji dotychczasowego systemu działania w rodzinie i społeczeństwie. Temu aktowi często towarzyszy napięcie i stres. Człowiek starszy, kończący pracę zawodową, traci związany z nią prestiż i pozycję. Sytuacja taka u wielu osób wywołuje poczucie bezużyteczności, odrzucenia i braku uznania. W następstwie swoistego odwrócenia ról, niedawni żywiciele i opiekunowie - czyli osoby zaspokajające potrzeby innych - stają się tymi, którzy niejednokrotnie sami potrzebują opieki, niekiedy także wsparcia finansowego. Przejście na emeryturę jest bowiem zwykle w naszym kraju równoznaczne z pogorszeniem warunków materialnych. Szczególnie dotkliwie mogą to odczuwać osoby przywiązujące wagę do zaszczytów i przywilejów związanych z zajmowanym stanowiskiem. Zaprzestanie pracy zawodowej oznacza utratę ważnej roli spolecznej, ale także ograniczenie kontaktów z dawnymi kolegami. Spora część emerytów stwierdza, iż tęskni za kolegami z pracy, doznaje wrażenia wyizolowania i osamotnienia. Uczucia te może potęgować nuda z powodu braku umiejętności zagospodarowania czasu wolnego, którego ilość gwałtownie wzrasta w momencie zakończenia pracy zawodowej ${ }^{29}$. Wiele osób, których życie było dotąd wypełnione pracą, nie

26 T.B. Kulik,M. Janiszewska-Grzyb, A. Pacian, Kształcenie ustawiczne ukierunkowane na zdrowie osób starszych [w:] Starość -obawy, nadzieje, oczekiwania. Wybrane zagadnienia z gerontologii, (red.) B. Zboina, G. Nowak-Starz, Ostrowiec Św. 2009, s. 143.

${ }^{27}$ H. Worach-Kordas, Wiek a petnienie ról społecznych, Warszawa-Łódź 1983, s. $111-123$

${ }^{28}$ B. Szatur-Jaworska, P. Błędowski, M. Dzięgielewska, Podstawy ..., s. 73.

29 A. A. Zych, Czlowiek wobec ..., s. 64. 
potrafi na emeryturze znaleźć sobie odpowiedniego zajęcia. Przymusowa bezczynność doprowadza ich do stanu apatii i przyspiesza procesy biologicznego oraz psychospołecznego starzenia.

Z badań M. Susułowskiej wynika, że mężczyźni zwykle gorzej znoszą przejście na emeryturę. Na ogół bardziej niż kobiety angażują się $\mathrm{w}$ pracę zawodowa, wykonując ją z ogromnym oddaniem, na dalszy plan odsuwają role rodzinne i towarzyskie oraz zainteresowania pozazawodowe. Po przejściu na emeryturę mają poczucie utraty prestiżu społecznego i odrzucenia. Zaniedbując przez wiele lat życie rodzinne, nie potrafią włączyć się w nie na starość, przez co pogłębia się ich osamotnienie. Natomiast kobiety, zwykle obarczone obowiązkami związanymi z prowadzeniem domu i wychowaniem dzieci, przyjmuja zaprzestanie pracy zawodowej z pewną ulgą. Kontynuowanie zajęć na rzecz rodziny wypełnia im czas oraz sprawia, że czują się potrzebne i użyteczne. Odchodząc z pracy nadal pełnią role - pani domu, matki, żony, wreszcie babci, co dla większości jest satysfakcjonujące i umożliwia samorealizację.

Zupełnie inny stosunek do emerytury przejawiają kobiety samotne, które rezygnując z życia rodzinnego, poświęciły się pracy zawodowej, oraz te, które przekonały się, że ich wolny czas nie jest nikomu potrzebny. Osoby, którym chciałyby go ofiarować bądź to zmarły, bądź przestały okazywać im swoje zainteresowanie i uczucia. Taka sytuacja może być odczuwana jako odrzucenie i powodować wystapienie u tych kobiet głębokiego poczucia pokrzywdzenia, rozgoryczenia i zniechęcenia ${ }^{30}$.

Generalnie sytuację przejścia na emeryturę łatwiej akceptują ludzie posiadający wyższe wykształcenie, przyjaciół, zainteresowania, prowadzący aktywny tryb życia.

Utratę kondycji fizycznej lub chorobę zaliczyć można do czynników kryzysogennych. Choroba może wiązać się z pogorszeniem sytuacji ekonomicznej, ograniczeniem ról społecznych, rodzinnych, które kiedyś się pełniło i które były dla jednostki ważne ${ }^{31}$. Choroba może

\footnotetext{
30 M. Susułowska, Niektóre aspekty pracy zawodowej ..., s. 121.
}

31 B. Zboina, Jakość życia osób starszych, Ostrowiec 2008, s. 70. 
prowadzić jednych do utraty chęci życia, rezygnacji i rozpaczy, innych, poprzez przeżywanie cierpienia, stymulować do walki z przeciwnościami losu.

Równie istotną sprawą są socjoekonomiczne warunki życia, których pogorszenie postrzegane jest jako jeden z głównych negatywów zaprzestania pracy zawodowej. Świadczą o tym wyniki badań przeprowadzonych przez J. Piotrowskiego, B. Tryfan, M. Susułowską i S. Nowaka przedstawiające, iż nawet w latach największej opiekuńczości państwa socjalistycznego osoby emerytowane nie należały do zbyt dobrze sytuowanych.

W ostatnich latach, w wyniku zmian politycznych, społecznych i gospodarczych nastapiła znaczna pauperyzacja społeczeństwa, szczególnie osób nie mogących się obronić, czyli niepełnosprawnych, z rodzin wielodzietnych, bezrobotnych oraz osób starszych, którzy często stają przed koniecznością wyboru - zaoszczędzić czy kupić. Mimo że posiadaja stały dochód, to najczęściej jest on tak niski, że nie są w stanie zapewnić sobie wszystkich potrzeb i ograniczaja je do minimum, a z niektórych rezygnują (zakup odzieży, leków, wyjazd, przyjęcie bliskich) ${ }^{32}$.

Prowadzone obecnie obserwacje życia codziennego osób starszych zwracają uwagę na problemy ludzi starszych mieszkających samotnie, pozbawionych pomocy w przypadku choroby, ograniczonej sprawności lub zniedołężnienia. Ludzie starsi, mieszkający samotnie, reprezentuja najbardziej słabą i zubożałą część społeczeństwa. Przyczynia się to do powstania dość niekorzystnej wizji starości, w której „funkcje mieszkania, (ochronne, ekonomiczne, biologiczne, kulturowe itp.) stają się coraz bardziej znaczące, a gdy sprawność ruchowa zostaje ograniczona, mieszkanie staje się „,całym światem”, a widok z okna zaczyna być istotnym elementem uczestnictwa w życiu społecznym" 33

Życie w samotności staje się z biegiem lat coraz bardziej skomplikowane, niesie ze sobą wiele wyzwań i trudności. Mieszkający samotnie z coraz większym trudem wykonują codzienne czynności, znacznie je

32 A. Leszczyńska-Rejchert, Człowiek starszy i jego wspomaganie - w stronę pedagogiki starości, Olsztyn 2007, s. 76.

33 Tamże, s. 78. 
ograniczając, lub nie są w stanie w ogóle ich wykonać. Mają zatem trudności w codziennym funkcjonowaniu. Jest to wynikiem fizjologicznych bądź patologicznych procesów starzenia się, występujących w różnych fazach życia seniora.

\section{PODSUMOWANIE}

Obecny, trudny okres transformacji przyniósł konsekwencje między innymi w postaci pauperyzacji dużych grup społeczeństwa. W warunkach braku stabilizacji gospodarczej, zachwiane zostało bezpieczeństwo socjalne osób utrzymujących się z rent i emerytur. Wraz z innymi grupami społecznymi ponoszą one skutki skomplikowanych przemian społeczno-gospodarczych, których jesteśmy świadkami. W najbliższych latach muszą nastapić zmiany w kreowaniu polityki społecznej skierowanej do osób starszych. Jej zadania winny skupiać się wokół potrzeb sędziwych osób starszych („czwarty wiek”) i koncertować się na zapewnieniu im odpowiednich usług zdrowotnych i opiekuńczych. W kolejnych latach należy skupić się na potrzebach młodych emerytów (,trzeci wiek), celem ułatwienia im adaptacji do emerytury i do nowych warunków życia ${ }^{34}$. Tempo wzrostu liczby emerytów i rencistów przewyższa zakładane skutki demograficznego starzenia. Zaspokojenie potrzeb zdrowotnych, ekonomicznych i kulturowych chociaż nie gwarantuje w sposób automatyczny dobrej adaptacji do starości, jest jednak bardzo istotne dla poczucia bezpieczeństwa i niezależności w starszym wieku. Polityka wobec starości jako fazy życia winna wspomagać jednostkę w radzeniu sobie z kryzysami rozwojowymi i sytuacyjnymi, tak typowymi dla tej fazy życia. Jej zadaniem jest również kształtowanie pozytywnego obrazu starości w świadomości społecznej, między człowiekiem starszym a jego otoczeniem. Przykładem tego typu działań jest ogłoszenie roku 2012, rokiem aktywności ludzi starszych i solidarności międzypokoleniowej ${ }^{35}$.

\footnotetext{
${ }^{34}$ B. Ziębińska, Uniwersytety Trzeciego Wieku jako instytucje przeciwdziałajace marginalizacji spotecznej, Katowice 2010, s. 54-58.

${ }^{35} \mathrm{http}: / /$ ec.europa.eu/social/2012
} 
Funkcjonowanie ludzi w podeszłym wieku wyznaczone jest zatem nie tylko przez zmiany biologiczne, następujące wraz z upływem czasu, ale przede wszystkim przez to, na ile identyfikują się oni z rolą człowieka starszego, zniedołężniałego, niepotrzebnego - wyznaczoną przez społeczny stereotyp starości. Odbiór tych determinantów, zarówno zewnętrznych, jak i wewnętrznych, decyduje o jakości życia osób starszych. Jednak, aby przystosowanie jednostki do sytuacji, w której się znalazła, odbywało się w harmonii z otaczającym ją światem, musi zaistnieć proces wychowawczy przygotowujący zarówno jednostkę, jak i społeczeństwo do pełnienia i odbioru nowych ról społecznych. To zagadnienie, uwidaczniające się przez mechanizmy przemian rozwojowych, szczególnie interesuje pedagogów.

Ludzie starsi ze względu na swoją sytuację życiowa, zdrowotna, społeczno-ekonomiczną są narażeni u schyłku życia na wiele sytuacji trudnych.

Kryzysy, które dotykają ludzi starszych, są przez nich przyjmowane w różny sposób. Jedni je akceptuja, poddają się, inni starają się sobie z nimi radzić. Radzenie sobie z kryzysem zależy jednak od wielu czynników, takich jak: właściwości osoby starszej (dojrzałość emocjonalna, wiara we własne siły), czynników związanych z sytuacją (np. zagrożenie zdrowia i życia), czynników środowiskowych (wsparcie rodziny, znajomych, środowiska).

Osoby, które nie potrafią poradzić sobie z sytuacjami kryzysowymi, są narażone na różnego rodzaju wpływy patologiczne, i wymagają szczególnej opieki i działania, tzw. interwencji kryzysowej. Polega ona na szybkim zdiagnozowaniu, ocenie poziomu zagrożenia życia i zdrowia osoby w kryzysie i jej najbliższego otoczenia celem podjęcia interwencji, która może umożliwić wyjście z kryzysu. Podczas diagnozy ocenia się najbliższe otoczenie osoby będącej w kryzysie, gdyż źródłem sytuacji kryzysowych nie zawsze jest wyłącznie jednostka będąca w kryzysie. Na źródło jej obecnych problemów i kłopotów składa się wiele czynników zewnętrznych, z którymi nie jest sobie sama w stanie poradzić.

W przetrwaniu kryzysów w starości może pomóc również dokonanie bilansu życia, korzystanie z gromadzonego w ciagu lat zapasu doświad- 
czeń i życiowej mądrości. Wyszukiwanie $\mathrm{z}$ całego pozytywnych cech pozwala na wyjście z kryzysu i zaakceptowanie starości jako kolejnego etapu życia.

\section{BIBLIOGRAFIA}

Andrews F. M., Withey S. B., Social indicators of well-being. Plenum, New York 1976.

Bień B., Nie wolno ignorować starości, „Magazyn Pielęgniarki i Położnej” 2001, nr 1, s. 10.

Birch A., Malim T., Psychologia rozwoju w zarysie. Od niemowlęctwa do dorostości, Warszawa 2001.

Czerniewska O., Wymiar czasu a przeżywanie starości, „Ethos” 1999, nr 47.

Glenn N.D., Weaver C.N., Educating effects on psychological wellbeing, Public Opinion Quarterly, 1981, nr 45.

http://ec.europa.eu/social/2012

Kulik T. B., Janiszewska-Grzyb M., Pacian A., Ksztatcenie ustawiczne ukierunkowane na zdrowie osób starszych [w:] Starość - obawy, nadzieje, oczekiwania. Wybrane zagadnienia z gerontologii, (red.) B. Zboina, G. Nowak-Starz, Ostrowiec Św. 2009.

James R. K., Gilliland B. E., Strategie Interwencji Kryzysowej, Warszawa 2006.

Leszczyńska-Rejchert A., Człowiek starszy $i$ jego wspomaganie, Olsztyn 2007.

Łukaszewski K., Szanse rozwoju osobowości, Warszawa 1974.

Pietrusiński Z, Rozwój człowieka dorosłego, Warszawa 1990.

Pilecka B., Kryzys psychologiczny, Kraków 2004.

Pufal-Struzik I, Poczucie osamotnienia i lęku u ludzi starszych, [w:] A. Jopkiewicz, E. Trafiałek (red.), Trzeci wiek bez starości, Kielce 2000.

Rembowski J., Psychologiczne problemy starzenia się czlowieka, Warszawa-Poznań 2000.

Sosnowski T., Wrzesiński K., Polska adaptacja Inwentarza STAI do badania stanu i cech leku, „Przegląd Psychologiczny” nr 2. 
Steuden S., Psychologia starzenia się i starości, Warszawa 2011.

Synak B, Teoretyczne i pojęciowe problemy złożoności w starszym wieku, [w:] J. Staręga-Piasek, B. Synak (red.), Społeczne aspekty starzenia się $i$ starości, Warszawa 1990.

Szatur-Jaworska B., Błędowski P., Dzięgielewska M., Podstawy gerontologii spolecznej, Warszawa 2006.

Wielka Encyklopedia PWN. T. 15, (red. nacz.) J. Wojnowski, Warszawa 2003.

Ziębińska B., Uniwersytety Trzeciego Wieku jako instytucje przeciwdziałajace marginalizacji osób starszych, Katowice 2010.

Zboina B., Jakość życia osób starszych, Ostrowiec 2008. 